\title{
Resiliensi dan Sabar sebagai Respon Pertahanan Psikologis dalam Menghadapi Post-Traumatic
}

\author{
Umi Rohmah \\ STAIN Ponorogo, Jawa Timur \\ e-mail: urohmah@yahoo.co.id
}

\begin{abstract}
Earthquake, accidents, the closure of the factory layoffs, rape, divorce, the death of the loved ones, poverty, suffering from a disease are many events which can be caused stress and frustration. Such incidents often cause trauma in individuals who do not have a strong psychological defenses. And if the trauma is not addressed properly will lead to post-traumatic disorder. A variety of unpleasant events raises a variety of different reactions. Some emotions burst out. There is also the emotion exploding inside. Some people describe themselves as victims. There are also some people who pass their distress by pointing to a new life and overcome a challenge. This paper tried to describe how resilience ability and sabar (patience) as a defense mechanism to face this psychological problems.
\end{abstract}

\section{Kata Kunci:}

Resiliensi, Sabar, Pertahanan Psikologis, Post-Traumatic

\section{A. Pendahuluan}

Pada tanggal 27 Mei 2006, terjadi gempa di Yogyakarta yang menewaskan lebih dari enam ribu orang dan merobohkan ratusan ribu rumah. Ribuan bahkan puluhan ribu orang berjalan cepat, berlari dan mengencangkan laju kendaraannya menuju arah gunung Merapi di utara Yogyakarta, gunung yang satu bulan sebelumnya diberitakan akan meletus. Ada juga yang berkomat-kamit membaca doa memohon keselamatan kepada Allah SWT. Mereka tidak ingin menjadi korban tsunami sebagaimana sebelumnya menelan korban ratusan ribu saudara-saudara mereka yang tinggal di Nangroe Aceh Darussalam (Nashori, 2008: 2). 
Masih segar dalam ingatan kita, peristiwa jatuhnya pesawat Sukhoi Superjet 100 di gunung Salak, Bogor pada Rabu, 9 Mei 2012 lalu. Puluhan orang tewas dalam peristiwa naas tersebut. Keluarga mereka sangat berduka atas kejadian ini. Hal ini sangat dimaklumi karena mereka kehilangan orang yang sangat dicintai untuk selama-lamanya (Kompas, 10 Mei 2012).

Gempa, kecelakaan, penutupan pabrik yang berakibat pada pemecatan karyawan, pemerkosaan, perceraian, ditinggal mati oleh orang yang dicintai, kemiskinan, menderita penyakit yang sulit untuk disembuhkan merupakan peristiwa-peristiwa yang tidak menyenangkan dalam kehidupan kita. Peristiwa-peristiwa tersebut terkadang menimbulkan trauma pada individu yang tidak memiliki pertahanan psikologis yang kuat. Dan trauma ini apabila tidak diatasi dengan baik akan mengarah pada gangguan post trauma.

Berbagai peristiwa yang tidak menyenangkan tersebut menimbulkan beragam reaksi yang berbeda. Beberapa orang emosinya meledak keluar. Ada juga yang emosinya meledak di dalam. Beberapa orang menggambarkan diri mereka sebagai korban. Ada juga sebagian orang yang melewati kesusahan mereka dengan mengarahkannya kepada kehidupan baru dan mengatasi sebuah tantangan. Mereka bangkit kembali, lebih kuat dan lebih baik dari sebelumnya. Orang seperti ini lah, yang oleh Al Siebert disebut sebagai orang yang resilien (Al Siebert, 2005: 2).

Jika para ilmuan di bidang psikologi melakukan banyak penelitian untuk mengkaji tentang bagaimana menghadapi post traumatik dengan resiliensi, maka Islam banyak membahas konsep sabar sebagai respon pertahanan psikologis dalam menghadapi post traumatik. Keduanya merupakan ketrampilan kecakapan hidup yang perlu dikembangkan oleh individu dalam rentang kehidupannya.

Tulisan ini akan diawali dengan pengertian post traumatik, respon pertahanan psikologis, resiliensi, sabar dan diakhiri dengan kaitan resiliensi dan sabar sebagai respon pertahanan psikologis dalam menghadapi post traumatik. 


\section{B. Post-Traumatik}

Ibrahim (2007: 125) mendefinisikan Post Traumatic Stres Disorder (PTSD) sebagai gangguan kecemasan yang terdiri dari: 1). Pengalaman tentang trauma melalui mimpi dan pikiran, 2). Penghindaran terhadap trauma dan 3). Kesadaran berlebihan yang persisten. Gangguan tersebut timbul apabila mengalami stres emosional/trauma psikologik yang besar yang berada di luar batas-batas pengalaman manusia yang lazim.

Prevalensi PTSD pada masyarakat umum sebesar $0.5 \%$ untuk pria dan $1.2 \%$ untuk wanita, anak-anak juga mengalami gangguan tersebut. Trauma untuk pria biasanya akibat pengalaman peperangan dan trauma untuk wanita paling sering adalah penyerangan atau pemerkosaan (Ibrahim, 2007: 125).

Lebih lanjut Ibrahim (2007: 126) mengatakan bahwa penelitian terakhir pada gangguan stres post traumatik sangat menekankan pada respon subjektif seseorang terhadap trauma ketimbang beratnya stresor itu sendiri. Walaupun gejala gangguan stres post traumatik pernah dianggap secara langsung sebanding dengan beratnya stressor, penelitian empiris telah membuktikan sebaliknya. Sebagai akibatnya, konsensus yang tumbuh menunjukkan bahwa gangguan ini memiliki pengaruh pada arti subjektif stresor bagi individu yang bersangkutan.

Sebagian orang mungkin tidak mengalami gejala gangguan stres post traumatik walaupun dihadapkan pada peristiwa traumatik yang berat. Demikian juga, peristiwa yang mungkin tampaknya biasa atau kurang berbahaya bagi kebanyakan orang, mungkin akan menyebabkan gangguan stres post traumatik pada beberapa orang karena arti subjektif dari peristiwa tersebut. Faktor kerentanan yang merupakan predisposisi memainkan peranan penting dalam menentukan apakah gangguan akan berkembang menjadi trauma post traumatik sebagian ditentukan oleh (Ibrahim, 2007: 126):
a. Adanya trauma masa kanak-kanak
b. Sifat gangguan kepribadian ambang, paranoid, dependen atau anti sosial
c. Sistem pendukung yang tidak adekuat
d. Kerentanan konstitusional genetika pada penyakit psikiatrik 
e. Perubahan hidup penuh stres yang baru saja terjadi

f. Persepsi tentang lokus kontrol eksternal dan

g. Penggunaan alkohol, walaupun belum sampai pada taraf ketergantungan

\section{Respon Pertahanan Psikologis}

Lazarus dan Laurier dalam Aliah (2008: 443) mendefinisikan respon pertahanan psikologis sebagai segala usaha, baik berorientasi pada tindakan atau intrapsikis, untuk mengelola (menguasai, mentolerir, mengurangi, meminimalkan) lingkungan dan tuntutan internal dan konflik di antaranya. Kemudian menurut Di Matteo dan Martin dalam Aliah (2008: 443) respon pertahanan psikologis merupakan segala upaya, baik berfokus pada masalah atau pun berfokus pada emosi, untuk mengelola kejadian yang penuh tekanan. Hal ini merupakan proses dinamik yang berpusat pada lima tugas utama, yaitu berhadapan secara realistik dengan masalah, mentolerir atau menyesuaikan diri secara emosional dari kejadian atau realita negatif, berusaha mempertahankan citra diri yang positip, berusaha mempertahankan keseimbangan emosional, dan berubah untuk meneruskan hubungan yang positip dengan orang lain. Respon pertahanan psikologis merupakan usaha individu untuk tetap dapat hidup sehat dalam menghadapi tekanan yang dihadapinya.

Ada berbagai respon pertahanan psikologis. Sigmund Freud dalam Gladding (2012: 235) mengidentifikasi respon pertahanan psikologis dalam berbagai cara berikut ini:

1. Represi, terjadi apabila pemilihan objek dipaksa keluar dari kesadaran ego, atau tekanan terhadap dorongan id, ego, dan super ego yang menimbulkan kecemasan. Sebagai contoh adalah seorang yang kehidupannya miskin terpaksa menekan keinginan-keinginannya untuk berbelanja pakaian-pakaian yang bagus.

2. Penyangkalan, memainkan peran defensif, sama seperti represi. Orang menyangkal untuk melihat atau menerima masalah atau 
aspek hidup yang menyulitkan. Denial beroperasi pada taraf prasadar atau sadar.

3. Regresi, ketika individu stres, seringkali dia kembali ke tingkah yang kurang dewasa.

4. Proyeksi, kalau terjadi kecemasan yang ditimbulkan id dan super ego, maka ego berusaha melemparkan sebab kecemasan kepada objek di luar diri agar ketegangan menjadi reda. Sebagai contoh jika seorang murid SMA nilai rapornya banyak yang merah, maka dia menyalahkan guru, karena guru tidak becus menerangkan pelajaran. Jadi kesalahan dirinya diproyeksikan kepada guru.

5. Rasionalisasi, mekanisme pertahanan ini melibatkan pemberian "alasan intelektual" untuk membenarkan suatu tindakan. Alasan dan tindakan tersebut hanya berhubungan dalam pikiran orang tersebut setelah tindakan selesai dilakukan.

6. Formasi reaksi, ketika seseorang berperilaku dalam cara yang merupakan kebalikan dari apa yang dia rasakan, hal itu dikenal dengan "formasi reaksi". Jenis tingkah laku ini biasanya bersifat melebih-lebihkan, seperti bersikap sangat baik pada orang yang tidak dia suka sama sekali.

7. Pergeseran, salah satu cara menghadapi anxietas adalah dengan memindahkannya dari objek yang mengancam kepada objek "yang lebih aman". Misalnya orang penakut yang tidak kuasa melawan atasannya, melampiaskan hostilitasnya di rumah kepada anak-anaknya di rumah.

Brooks dan Goldstein (2009: 90) mengemukakan bahwa individu yang tahan terhadap stres adalah individu yang:

1. Memiliki komitmen. Komitmen terhadap relasi, pekerjaan, aktivitas sosial dan praktik keagamaan.

2. Menyukai tantangan. Individu yang tahan stres adalah individu yang menganggap situasi sulit sebagai tantangan yang menjadi sumber belajar bukan sebagai alasan untuk merasa kalah 
3. Memiliki kontrol pribadi. Individu yang memiliki kontrol pribadi akan mencurahkan waktu dan energinya pada penyelesaian masalah, ia tidak menuntut orang lain untuk berubah tapi dirinya sendiri yang berubah terlebih dahulu.

Menurut Delyse, ketika individu menghadapi stres dan trauma, maka ia akan meresponnya dengan dua cara, yakni:

1. Dengan melawannya (fight). Ini merupakan bagian dari sistem pertahanan kita yang akan membantu kita bersiap-siap untuk menghadapi ancaman

2. Dengan membiarkannya (freeze). Respon ini akan mengakibatkan individu merasa tidak berdaya, mati rasa, putus asa, merasa malu pada diri sendiri, merasa kesulitan untuk membuka diri dengan orang-orang yang berada di sekitar kita, merasa cemas dan panik dan merasa tidak aman di manapun kita berada. ${ }^{1}$

Sedangkan menurut Al Siebert (2004: 1-2) ada berbagai respon yang dilakukan orang ketika ia dihadapkan pada kejadian-kejadian yang tidak menyenangkan, yaitu:

1. Emosinya meledak keluar. Orang yang merespon dengan cara ini akan menjadi cepat marah ketika ia dihadapkan pada peristiwa-peristiwa yang tidak menyenangkan. Bahkan terkadang ia menyerang orang-orang yang berada di sekitarnya

2. Emosinya meledak ke dalam. Orang yang merespon dengan cara ini akan mengalami mati rasa, merasa tidak bahagia dan ia tidak mencoba untuk menghadapi masalahnya.

3. Menganggap dirinya sebagai korban. Orang yang merespon dengan cara ini akan menganggap bahwa "hidup ini tidak adil", ia juga menganggap orang lain sebagai penyebab masalah dalam hidupnya

4. Meresponnya dengan resiliensi. Orang yang merespon dengan cara ini menganggap masalah sebagai sebuah tantangan yang harus dihadapi. Ia mengarahkan dengan cepat terhadap

www.trauma.vancouver.com 
kehidupan baru. Ia bangkit kembali dan merasa yakin akan tujuannya. Ia memiliki bakat untuk menciptakan keberuntungan yang baik dari keadaan yang menurut orang lain adalah sebaliknya.

Islam banyak membahas konsep sabar sebagai respon pertahanan psikologis manusia dalam menghadapi ujian-ujian hidup yang terentang sepanjang kehidupan manusia. Frekuensi penyebutan kata sabar dalam al-Qur'an cukup tinggi. Muhammad Fuad Abd al-Baqi dalam Aliah (2008: 44) menyebutkan kata sabar dengan berbagai perubahan bentuknya disebut sebanyak 101 kali di dalam al-Qur'an tersebar pada 92 ayat dan 45 surat.

\section{Resiliensi}

\section{Definisi resiliensi}

Istilah resiliensi diintrodusir oleh Redl pada tahun 1969 dan digunakan untuk menggambarkan bagian positip dari perbedaan individual dalam respon seseorang terhadap stres dan keadaan yang merugikan (adversity) lainnya. Tetapi hingga tahun 1980-an, istilah resiliensi belum digunakan secara konsisten. Istilah resiliensi diadopsi sebagai ganti dari istilah-istilah yang sebelumnya telah digunakan oleh para peneliti untuk menggambarkan fenomena, seperti: "invulnerable" (kekebalan) "invincible" (ketangguhan), dan "hady" (kekuatan), karena dalam proses menjadi resilien tercakup pengenalan perasaan sakit, perjuangan dan penderitaan (Desmita, 2009: 199).

Reivich dan Shatte (2002: 26) memandang resiliensi sebagai kapasitas individu untuk merespon dengan cara-cara yang sehat dan produktif ketika individu menghadapi adversitas atau trauma. Lebih lanjut Reivich dan Shatte (2002: 46) menandaskan bahwa resiliensi bukan hanya kapasitas individu untuk mengatasi, memandu keluar, dan bangkit kembali dari masalah atau adversitas, tetapi resiliensi juga membantu individu meningkatkan aspek-aspek positip dari kehidupan.

Al Siebert (2004: 5) mendefinisikan resiliensi sebagai kemampuan individu untuk bangkit kembali dari keterpurukan yang terjadi dalam perkembangannya. Awalnya mungkin ada tekanan yang mengganggu. Namun orang-orang dengan resiliensi yang tinggi akan mudah untuk 
kembali ke keadaan normal. Mereka mampu mengelola emosi mereka secara sehat. Mereka punya hak dan berhak untuk merasa sedih, marah, merasa kehilangan, sakit hati dan tertekan tetapi mereka tak membiarkan perasaan itu menetap dalam waktu lama. Mereka cepat memutus perasaan yang tidak sehat, yang kemudian justru membantunya tumbuh menjadi orang yang lebih kuat.

\section{Ciri-ciri individu yang resilien}

Individu yang resilien adalah individu yang tidak memunculkan simton patologis pada situasi-situasi yang cenderung negatif, mengancam dan dapat mengatasi kejadian negatif tersebut untuk hidup secara berkualitas. Secara lebih spesifik, ciri-ciri individu yang memiliki kemampuan resiliensi adalah sebagai berikut (Al Siebert, 2004: 5):

a. Dapat mengatasi perubahan-perubahan dalam hidup

b. Dapat mempertahankan kesehatan dan energi yang baik ketika berada dalam tekanan

c. Dapat bangkit dari keterpurukan

d. Dapat mengatasi kesulitan-kesulitan hidup

e. Dapat merubah cara berfikir dan cara mengatasi masalah ketika cara yang lama tidak berhasil

f. Dapat melakukan hal-hal di atas tanpa melakukan tindakan yang tidak sesuai (berbahaya) atau disfungsi.

\section{Signifikansi resiliensi}

Resiliensi adalah faktor penting dalam kehidupan kita sekarang ini. Ketika perubahan dan tekanan hidup berlangsung begitu intens dan cepat, maka seseorang perlu mengembangkan kemampuan dirinya sedemikian rupa untuk mampu melewati itu semua secara efektif. Untuk mampu menjaga kesinambungan hidup yang optimal, maka kebutuhan akan kemampuan untuk menjadi resilien sungguh menjadi makin tinggi.

Orang-orang dengan resiliensi yang tinggi, akan mampu keluar dari masalah dengan cepat dan tak terbenam dengan perasaan sebagai 
korban lingkungan atau keadaan. Masih menurut Al Siebert (2004: 6), ia menegaskan bahwa di tengah dunia yang berubah cepat ini, maka:

a. Perusahaan dengan karyawan yang resilien akan memiliki keuntungan dibanding kompetitor mereka.

b. Saat banyak tekanan untuk melakukan efisiensi dan restrukturisasi, dengan downsizing misalnya, maka pekerja resilien dengan ketrampilan yang beragam lah yang akan dipertahankan

c. Saat melamar pekerjaan, orang-orang dengan resiliensi yang tinggi lah yang lebih punya kesempatan

d. Di tengah tekanan ekonomi yang ada, keluarga dengan individu yang resilien di dalamnya lah yang akan cepat keluar dari krisis.

e. Pribadi dengan resiliensi tinggi lah yang cepat mengambil keputusan saat berada dalam situasi sulit

f. Mereka juga adalah pribadi yang tidak mudah sakit saat banyak diterpa masalah.

\section{Upaya mengembangkan resiliensi}

Al Siebert (2004: 10) mengemukakan langkah-langkah untuk mengembangkan ketrampilan resiliensi dan membangun kekuatan individu mengikuti hirarki lima tingkatan, yaitu:

a. Meningkatkan kesehatan dan energi. Adapun faktor-faktor yang mempengaruhi kesehatan individu:

1). Tidak terlalu merasa stress dalam setiap aktivitas

2). Merasa bahwa hidup kita dikontrol oleh kekuatan diri kita sendiri bukan oleh orang lain

3). Merasa nyaman dalam berhubungan dengan keluarga dan teman

4). Bertanggung jawab

5). Bisa mengatur perubahan diri dengan baik

6). Mengembangkan kebiasaan gaya hidup sehat 
7). Menjadikan pengalaman-pengalaman negatif menjadi pelajaran yang menguntungkan

8). Menikmati pengalaman-pengalaman positip

b. Memiliki ketrampilan menyelesaikan masalah

Robert Sternberg dalam Al Siebert (2004: 56) mengemukakan ada tiga jenis kecerdasan yang berpengaruh terhadap kesuksesan hidup. Tiga jenis kecerdasan tersebut adalah: kecerdasan analitik (analytical intelligence), kecerdasan kreatif (creative intelligent) dan kecerdasan praktis (practical intelligence).

c. Memperkuat diri dengan tiga kekuatan diri: Percaya diri, harga diri dan konsep diri

Ada tiga kekuatan yang esensial di dalam diri kita, yaitu: self confident, self esteem dan self concept. Jika ketiga self ini kuat maka akan mengembangkan talenta, kemampuan dan menjadi kekuatan resiliensi. Sebaliknya, jika lemah maka akan menurunkan resiliensi dan kesehatan individu (Al Siebert, 2004: 73).

d. Optimis

Oxford Dictionary mendefinisikan optimisme sebagai memiliki "harapan dan keyakinan tentang masa depan atau hasil yang sukses dari sesuatu". Kecenderungan untuk mengambil pandangan positip atau penuh harapan. Kata ini awalnya berasal dari optimal (Latin) yang berarti terbaik. Menjadi optimis, dalam arti khas kata, pada akhirnya berarti mengharapkan hasil terbaik dari situasi tertentu. ${ }^{2}$

Harapan dan optimis berkontribusi terhadap resiliensi sebab keduanya berorientasi pada masa depan. Individu yang penuh dengan harapan dan optimis mampu bangkit kembali dan mampu membuat sesuatu menjadi lebih baik dari sebelumnya. Sebuah "harapan" akan membantu individu melewati masamasa sulit. Optimis, akan membantu individu berfikir dan

${ }^{2}$ www.id.shvoong.com 
berimajinasi bahwa segala sesuatu akan berjalan dengan baik (Al Siebert, 2004: 115).

e. Empati

Kemampuan empati merupakan kemampuan untuk melihat dan mengetahui kondisi emosional dan psikologis orang lain. Hal ini termasuk mampu untuk melihat dan mengerti pesan non verbal, ekspresi nada suara dan gerakan tubuh dari orang lain. Individu yang tidak memiliki kemampuan ini tidak dapat menempatkan dirinya pada orang lain dan memprediksi apa yang dirasakan oleh orang lain. Individu yang tidak mampu berempati akan terus terjebak pada karakternya yang tidak resilien karena ia tidak berusaha untuk mencoba meningkatkan diri dengan memahami orang lain.

\section{E. Sabar}

Musibah dan penderitaan di dunia merupakan sebuah keharusan, siapa pun tidak bisa terlepas darinya. Bahkan, itulah warna-warni kehidupan. Kesabaran dalam menghadapi musibah dan penderitaan merupakan tanda kebenaran dan kejujuran iman seseorang kepada Allah SWT. Sesungguhnya musibah dan penderitaan yang datang bertubi-tubi menerpa hidup manusia merupakan satu ketentuan yang telah ditetapkan Allah SWT. Tidak satu pun di antara kita yang mampu menghalau ketentuan tersebut.

Keimanan, keyakinan tawakkal dan kesabaran yang kokoh sangat dibutuhkan dalam menghadapi badai kehidupan yang menerpa. Sehingga tidak menjadikan kita berburuk sangka kepada Allah SWT. terhadap segala ketentuan-Nya.

Oleh karena itu, dalam keadaan apa pun, kita sebagai hamba yang beriman kepada Allah harus senantiasa berbaik sangka kepada Allah. Dan haruslah diyakini bahwa tidaklah Allah menurunkan berbagai musibah melainkan sebagai ujian atas keimanan yang kita miliki. Sebagaimana Allah berfirman:

Apakah kamu mengira bahwa kamu akan masuk syurga, padahal belum datang kepadamu (cobaan) seperti (yang dialami) orangorang terdahulu sebelum kamu? Mereka ditimpa kemelaratan, 
penderitaan dan diguncang (dengan berbagai cobaan), sehingga rasul dan orang-orang yang beriman bersamanya berkata: "Kapankah datangnya pertolongan Allah?" Ingatlah, sesungguhnya pertolongan Allah itu dekat (Al-Baqarah: 214)

Kesabaran merupakan perkara yang sangat dicintai oleh Allah dan sangat dibutuhkan seorang muslim dalam menghadapi musibah dan penderitaan yang dialaminya. Sebagaimana dalam firman-Nya: ... Dan Allah mencintai orang-orang yang sabar (Al-Imran: 146).

\section{Makna Sabar}

Kata sabar (ash-shabr) makna asalnya adalah menahan atau mengurung. Sabar berarti menahan jiwa untuk tidak berkeluh kesah, menahan lisan untuk tidak meratap, dan menahan anggota badan untuk tidak menampar pipi, merobek baju dan sebagainya (Al-Qayyim, 2006: 25).

Ibnu al-Qayyim (2006: 37) membagi sabar berdasarkan bentuknya menjadi dua macam, kesabaran jasmani dan kesabaran jiwa.

Kesabaran jasmani dibagi menjadi dua:

a. Kesabaran jasmani secara sukarela, misalnya sabar dalam melakukan pekerjaan berat atas pilihan dan kehendaknya sendiri

b. Kesabaran jasmani oleh faktor keterpaksaan, misalnya sabar dalam menahan rasa sakit akibat pukulan, sabar menahan penyakit, menahan dingin, panas dan sebagainya.

Sedangkan kesabaran jiwa dibagi menjadi dua macam, yakni:

a. Kesabaran jiwa secara sukarela, misalnya kesabaran menahan diri untuk melakukan perbuatan yang tidak baik berdasarkan pertimbangan syariat agama dan akal.

b. Kesabaran jiwa oleh faktor keterpaksaan, seperti kesabaran berpisah dengan orang yang dikasihi jika cinta terhalang.

Achmad Mubarok (2001: 73) mendefinisikan sabar sebagai tabah hati tanpa mengeluh dalam menghadapi godaan dan rintangan dalam jangka waktu tertentu dalam rangka mencapai tujuan. Karena sabar 
bermakna kemampuan mengendalikan emosi, maka nama sabar berbeda-beda tergantung objeknya:

a. Ketabahan menghadapi musibah, disebut sabar, kebalikannya adalah gelisah dan keluh kesah

b. Kesabaran menghadapi godaan hidup nikmat disebut mampu menahan diri (dhobith an nafs), kebalikannya adalah tidak tahanan (bathar)

c. Kesabaran dalam peperangan disebut pemberani, kebalikannya disebut pengecut

d. Kesabaran dalam menahan marah disebut santun (hilm), kebalikannya disebut pemarah (tazammur)

e. Kesabaran dalam menghadapi bencana yang mencekam disebut lapang dada, kebalikannya disebut sempit dadanya

f. Kesabaran dalam mendengar gosip disebut mampu menyembunyikan rahasia

g. Kesabaran terhadap kemewahan disebut zuhud, kebalikannya disebut serakah

h. Kesabaran dalam menerima yang sedikit disebut kaya hati (qana'ah) kebalikannya disebut tamak atau rakus.

Sabar merupakan suatu yang bersifat dinamik. Umat Islam melihat dinamika kesabaran sebagai lingkaran yang berasal dari Allah dan kembali kepada Allah. Dengan sifatnya yang dinamik, sabar bukan sesuatu yang bersifat pasif. Sabar bukanlah tunduk dan patuh tanpa perlawanan dan usaha melainkan perjuangan dan upaya dengan tetap memelihara ketabahan jiwa dan keyakinan akan hasil yang baik. Dalam hal ini, terdapat tanggapan yang kurang tepat tentang kesabaran. Umat Islam yang awam dengan ajaran agamanya memahami arti kata ini secara parsial, yakni hanya menekankan pada aspek kepasrahan di dalam menghadapi kesulitan hidup. Pemahaman mereka cenderung mengarah kepada sikap yang pasif di dalam menerapkan gagasan ini (Purwakania, 2008: 446-447). 


\section{Keutamaan Sabar}

a. Pujian Allah terhadap orang-orang yang sabar

Allah memuji orang-orang yang benar dalam keimanannya, sebagaimana firman-Nya: ...dan orang-orang yang sabar dalam kesempitan, penderitaan dan dalam peperangan. Mereka itulah orang yang benar (imannya). Dan mereka itulah orang-orang yang bertakwa. (QS. Al-Baqarah: 177)

b. Allah mencintai orang yang sabar (Al-Imran: 146)

c. Mendapat ampunan dari Allah

"Kecuali orang-orang yang sabar (terhadap bencana) dan mengerjakan amal-amal saleh, mereka itu memperoleh ampunan dan pahala yang besar (Hud: 11).

d. Mendapat martabat yang tinggi di surga

"Mereka itulah orang yang dibalas dengan martabat yang tinggi (dalam syurga) karena kesabaran mereka dan mereka disambut dengan penghormatan dan ucapan selamat di dalamnya (Al-Furqan: 75).

\section{Tingkatan Sabar}

Menurut Mubarok (2001: 74), ada tiga tingkatan orang sabar:

a. Orang yang dapat menekan habis dorongan hawa nafsu hingga tidak ada perlawanan sedikit pun, dan orang itu bersabar secara konstan. Mereka adalah orang yang sudah mencapai tingkat shiddiqin

b. Orang yang tunduk total kepada dorongan hawa nafsunya sehingga motivasi agama sama sekali tidak dapat muncul. Mereka termasuk kategori orang-orang yang lalai (alghofilun)

c. Orang yang senantiasa dalam konflik antara dorongan hawa nafsu dengan dorongan keberagamaan. Mereka adalah orang yang mencampuradukkan kebenaran dengan kesalahan. 


\section{Langkah-langkah yang bisa menguatkan kesabaran}

Berikut ini beberapa tips yang diberikan oleh Ibn al-Qayyim (2006: 88-89) untuk menguatkan kesabaran seseorang:

a. Hendaknya ia memaklumi faktor yang membangkitkan nafsu birahi terletak pada makanan yang mengandung unsur-unsur pembangkit berdasarkan jenis dan kuantitasnya. Dalam hal ini, hendaknya ia memutuskan untuk mengurangi jenis makanan itu. Jika tidak dapat diatasi, hendaknya ia berpuasa. Sebab, puasa itu melemahkan saluran syahwat dan melumpuhkan ketajamannya, teristimewa jika ia makan secukupnya di waktu sahur.

b. Menjauhkan diri dari berbagai unsur yang dapat menggerakkan hasrat birahi, dalam hal ini adalah menjaga pandangan mata. Dalam hal ini, ia dituntut untuk mengendalikan penglihatan sedapat mungkin, sebab faktor hasrat dan keinginan birahi itu akan menggelora melalui pandangan mata dan menggerakkan hati untuk bernafsu.

c. Menenangkan batin dengan melakukan perbuatan mubah yang dapat menjadi pengganti perbuatan haram. Sebab, segala yang diinginkan oleh hawa nafsu akan dapat tercukupi dengan apa yang dihalalkan Allah.

d. Merenungkan dampak-dampak buruk yang ditimbulkan dari perbuatan melampiaskan hawa nafsu dengan menempuh caracara yang tidak halal.

Malahayati (2002: 114-115) juga memberikan beberapa tips untuk meningkatkan kesabaran:

a. Mengikhlaskan niat karena Allah. Sabar hendaknya disertai dengan keikhlasan. Karena bukan sabar namanya jika tidak ikhlas. Dan niat kita melakukan segala sesuatu hendaknya karena Allah, termasuk juga niat bersabar. Karena segala ibadah bergantung pada niat.

b. Memperbanyak tilawah al-Qur'an disertai dengan tadabbur.

Bacaan al-Qur'an mempunyai efek psikologis menenangkan hati kita. Apalagi jika disertai tadabbur dan suara yang tartil, 
sungguh menjadi pengobat hati yang sedang sakit. Bahkan bisabisa kita menangis. Orang yang tenang dengan bacaan alQur'an bisa menjadi orang yang lebih sabar dalam menghadapi cobaan hidup.

c. Bersungguh-sungguh menahan nafsu. Nafsu yang ada dalam diri kita tidak bisa kita bunuh 100 \%. Yang bisa kita lakukan adalah menggendalikannya dan mengembalikan pada jalurnya yang benar. Maka kita harus menguatkan diri untuk sungguhsungguh menahan nafsu.

d. Memperbanyak membaca kisah orang sabar.

Kisah para nabi, sahabat nabi, para ulama, tokoh-tokoh terkenal, dan juga kisah sederhana dalam keseharian juga akan menguatkan kita bahwa tidak hanya kita sendiri yang pernah mendapatkan cobaan dan bahwa orang-orang yang pernah mengalami cobaan bisa mengatasinya dengan kesabaran. Maka demikian juga dengan kita.

e. Latihan sabar secara pribadi

Latihan terhadap hal-hal sederhana. Misalnya, sabar ketika teman terlambat datang, sabar menunggu angkutan, sabar ketika ada kekurangan pasangan hidup, sabar dan tidak marah dengan hal-hal sepele yang tidak penting.

f. Memperbanyak puasa sunah.

Puasa mempunyai efek mengendalikan nafsu ingin marah dan nafsu-nafsu lainnya. Karena itu rajin puasa sunnah bisa menjadi terapi bersikap sabar.

g. Mengingat tujuan hidup di dunia.

Tujuan hidup muslim di dunia ini adalah beribadah kepada Allah SWT. Lalu mengapa karena hal-hal kecil dan sepele kita tak bisa bersabar. Hendaknya senantiasa kita ingat tujuan hidup kita yang besar, agar tidak terpengaruh dengan permasalahan-permasalahan sepele. 


\section{F. Resiliensi dan Sabar sebagai Respon Pertahanan Psikologis dalam Menghadapi Post Traumatik}

Problem atau masalah merupakan bagian dari hidup kita. Kehadiran masalah bukan yang menentukan kebahagiaan dan ketentraman hidup kita. Kebahagiaan dan ketentraman hidup lebih ditentukan oleh bagaimana kita bertindak dan menghadapi masalah. Masalah bukan untuk dihindari, tapi masalah merupakan tantangan yang harus dicari jalan keluarnya. Karena apabila masalah itu dibiarkan, maka masalah itu akan membuat kita mengalami gangguan kecemasan. Dan gangguan kecemasan yang sangat parah sebagai akibat dari peristiwa traumatik bisa menjadikan sebagian orang tidak bisa meresponnya dengan efektif. Menurut penulis, hal ini tidak akan terjadi ketika kita memiliki sifat "resiliensi dan sabar".

Resiliensi dan sabar merupakan pertahanan psikologis seseorang yang akan membantunya menjalani hidup dengan sehat. Hidup yang sehat tidak sekedar sehat secara fisik, tetapi hidup yang sehat adalah meliputi juga mental yang sehat. Mental yang sehat idealnya tidak dipandang dari prespektif klinis saja, tapi juga dari perspektif edukatif dan pedagogis. Orang yang mentalnya sehat adalah orang yang tidak mengingkari masalah kehidupan. Karena sejatinya manusia itu berada dalam kehidupan itu sendiri. Dengan demikian, manusia yang mentalnya sehat adalah manusia yang mampu mensyukuri hidup. Ia tidak mudah mengeluh dalam menghadapi problema kehidupan. Karena sesungguhnya manusia dibekali berbagai potensi untuk memecahkan problema hidup. Dan sejatinya Allah tidak membebani hamba-Nya melainkan sesuai dengan kapasitasnya (Q.S. al-Mukminun : 62; alBaqarah: 286). Artinya, setiap manusia punya potensi mampu menyelesaikan problem kehidupan. Dan tidak ada manusia yang tidak lulus dari ujian kehidupan. Lalu mengapa ada diantara manusia yang tidak mampu menghadapi problem kehidupan? Jawabannya, syaitan telah membisikkan rasa was-was, ragu, khawatir dan cemas pada diri manusia (Q.S. an-Nas: 4-5), sehingga mestinya manusia mampu menghadapi problem hidup menjadi tidak berdaya karena bisikan setan.

Apa yang harus dilakukan manusia ketika syaiton membisikkan rasa cemas, was-was, dan khawatir pada hati manusia? Manusia harus segera sadar dan kembali mengingat Allah (dzikrullâh) sehingga segala 
kekuatan dan potensinya akan berfungsi normal lagi. Kita sadari bahwa masalah itu datangnya dari Allah. Kita kembalikan masalah itu kepada Allah. Kita hadirkan Allah dalam setiap desahan nafas kita. Kita minta tolong kepada Allah supaya masalahnya diselesaikan oleh Allah sembari kita tetap meluruskan niat dan tetap mengoptimalkan ikhtiar.

Menjadi bahagia atau tidak bahagia adalah sebuah pilihan (Rakhmat, 2004: 5). Maka penulis percaya, tidak ada orang di dunia ini yang memilih untuk tidak bahagia. Bahagia bisa diusahakan dengan menjalani hidup sesuai dengan aturan-Nya. Hanya manusia yang mempunyai mental yang sehat, pola fikir yang sehat, daya adaptasi dan fleksibelitas, kemampuan berkomunikasi dan berkolaborasi, pantang menyerah, tangguh, optimis dan sandaran pada yang Maha Pencipta-lah (baca: manusia yang resilien dan sabar) yang akan mampu menghadapi segala problem kehidupan dan akan meraih kebahagiaan.

Sebagai pendidik, pembimbing, guru BK, konselor, sukarelawan kemanusiaan, praktisi pendidikan, kyai, tokoh masyarakat dan apa pun status kita, mari kita fasilitasi anak didik kita dengan berbagai ketrampilan hidup, diantaranya ketrampilan resiliensi dan sabar. Resiliensi dan sabar bisa dipelajari dan dikembangkan di kelas, tempat umum, masjid, pasar, sawah dan di mana pun kita berada.

\section{G. Penutup}

Berbagai respon pertahanan psikologis dilakukan manusia ketika dihadapkan pada problem kehidupan. Resiliensi dan sabar merupakan sebagian dari sistem pertahanan psikologis manusia. Kepemilikan ketrampilan resiliensi dan sabar sangat urgen bagi tiap individu untuk menghadapi problem kehidupan, termasuk gangguan kecemasan post traumatik.

Setiap individu pada hakikatnya mempunyai resiliensi dan kesabaran, namun masing-masing individu memiliki tingkatan yang berbeda-beda. Kualitas resiliensi dan kesabaran bisa dipelajari dan dikembangkan oleh siapa pun yang menginginkan hidupnya berbahagia dan berkualitas. Kontinuitas dalam mengembangkannya adalah "mutlak adanya".[] 


\section{DAFTAR PUSTAKA}

Tim Penyusun. 2012. Al-Qur'anul Karim. Miracle The Reference. Bandung: Sigma Publishing

Al Siebert. 2004. The Resiliency Advantage. San Francisco: BerretKoehler.

Al-Jauziyyah, Ibnu al-Qayyim. 2009. 'Uddatu Ash-Shabirin wa Dzakhiratu asy-Syakirin. Terj. A.M. Halim. Jakarta: Maghfirah Pustaka.

Brooks, Robert \& Sam Goldstein. 2009. The Power of Resilience. Terj. Burhan Wirasubrata. Jakarta: Serambi Ilmu Semesta.

Desmita. 2009. Psikologi Perkembangan Peserta Didik. Bandung: Remaja Rosdakarya.

Gladding, Samuel, T. 2012. Counseling: A Comprehensive Profession. Terj. P.M. Winarno \& Lilian Yuwono. Jakarta: Indeks.

Hasan, Aliah B. Purwakania. 2008. Pengantar Psikologi Kesehatan Islami. Jakarta: Rajawali Press.

Ibrahim, Ayyub Sani. 2007. Panik Neurosis dan Gangguan Cemas. Jakarta: REF Graphika.

Kompas, 10 Mei 2012.

Mubarok, Ahmad. 2001. Psikologi Qur'ani. Jakarta: Pustaka Firdaus.

Malahayati. 2002. Ketika Wanita Harus Bersabar. Semarang: Pustaka Widyamara.

Nashori, Fuad. 2008. Psikologi Sosial Islami. Bandung: Refika Aditama.

Reivich, Karen \& Andrew Shatte. 2002. The Resilience Factor: 7 Essential Skill for Overcoming Life's Inevitable Obstacles. New York: Broadway Books.

Rakhmat, Jalaludin. 2004. Meraih Kebahagiaan. Bandung: Simbiosa Rekatama Media. http://www.trauma.vancouver.com.

http://www.id.shvong.com/social-sciences/psychology/2198692pengertian-optimis/\#ixzzlvslcBN12 